\title{
Political Science in Canada on Post-Independence Ukraine
}

\author{
Ivan (John) Jaworsky \\ University of Waterloo
}

\begin{abstract}
When Ukraine became an independent state, Canada's political science community, and the country's Ukrainian studies infrastructure, generally lacked the expertise to effectively analyze the ensuing political changes in Ukraine. Over the years that followed there has been a growing awareness of the importance of studying politics in Ukraine, and a realization that greater efforts should be made to infuse the traditional area studies approach, which dominated studies of Ukraine in the past, with greater methodological rigour, and to situate political developments in Ukraine within a broad comparative context. As a result, Canadian academics are now in a much stronger position to contribute to the study of politics in Ukraine. There is, however, much room for improvement.
\end{abstract}

Keywords: Ukraine, Canada, politics, political science, Ukrainian studies, comparative politics.

\section{INTRODUCTION}

T $\mathrm{n}$ Canada, with the end of the Cold War and the demise of the Soviet Union, both political and scholarly interest in the post-Soviet region declined. However, between the late 1980s and the early 1990s Ukraine, which most mainstream Sovietologists had earlier regarded as a peripheral backwater of the USSR, acquired all the formal attributes of a full-fledged state and began attracting attention as a new and potentially significant political actor in the post-Soviet region. Scholars in Canada with specific interests in Ukraine, or those who could now include Ukraine in one of many categories of states (e.g., countries in transition, democratizing states, postcommunist states) that are subject to comparative analysis, now had a wide range of opportunities for research and collaboration with scholars in Ukraine.

At the time of Ukraine's independence, Canada already had a number of academic institutions that focused on the study of Ukraine. The two most prominent were the Canadian Institute of Ukrainian Studies (CIUS) ${ }^{1}$

\footnotetext{
${ }^{1}$ Unless indicated otherwise, all information in this article about the CIUS and its activities was located at https://uofa.ualberta.ca/arts/research/canadian-instituteukrainian-studies. Details concerning all of these activities can be found in the CIUS's
} 
established in 1976 at the University of Alberta, and the Chair of Ukrainian Studies founded in 1980 (renamed the John Yaremko Chair of Ukrainian Studies in 2010) at the University of Toronto. Early awareness of the importance of studying politics in Ukraine was reflected in the appointment in 1976 of a political scientist, Bohdan Krawchenko, as one of the CIUS's first two research associates. He later served as the director of the CIUS from 1986 to 1991, the crucial period that immediately preceded Ukraine's independence. In addition, the holder of the Chair of Ukrainian Studies was designated a joint appointee of the University of Toronto's Departments of History and Political Science.

Soon after Ukraine's independence, however, a number of highlyrespected senior Canadian political scientists who were productive specialists on Ukraine, or on nationality issues in the Soviet Union, retired. They included Bohdan R. Bociurkiw (Carleton University), Peter J. Potichnyj (McMaster University), and Teresa Rakowska-Harmstone (Carleton University). Krawchenko's active involvement with the CIUS ended in 1991, when he left Canada for Ukraine. Initially he was on leave from the University of Alberta to conduct research in Ukraine, but he soon became involved in a number of major initiatives in Kyiv to promote administrative reform in Ukraine and participated in a number of Ukrainian government committees, task forces, and working groups. Krawchenko decided to stay and work in Kyiv as founding director of the Institute of Public Administration and Local Government (est. 1992) of the Cabinet of Ministers. He also served as vicerector for academic development and director of the Centre for the Study of Administration Reform of that institute's successor, the Academy of Public Administration (est. 1995) of the Office of the President of Ukraine. In 2004 Krawchenko joined the University of Central Asia (founded in 2000) in Bishkek, where he is currently the director general and dean of graduate studies ("UCA Staff").

New challenges to studying Ukraine emerged from the late 1980s onward as the University of Alberta reduced its funding for the CIUS. The prospect of significant cutbacks inspired the CIUS to attract more private donors and increase permanent endowments. However, some members of the Ukrainian diaspora had supported Ukrainian studies in the West because such studies were perceived to counter Soviet efforts to Russify Ukraine and distort scholarship regarding Ukraine, and the emergence of a post-Soviet Ukraine that many hoped would rapidly reject its Soviet legacies dissipated some of the motivation to support Ukrainian studies in the West. Potential

annual newsletters; those issued since the autumn of 2003 are available at the above website. 
donor funds now were often shifted to support a variety of new institutions and good causes in Ukraine. ${ }^{2}$

Thus the new opportunities for research, academic exchanges and cooperation that emerged after Ukraine gained independence, coincided with a number of significant challenges to Canadian scholarship regarding Ukraine. This article addresses some of the ways Canada's Ukrainian studies and political science communities, as well as certain scholars who are not political scientists but who conduct research that is, or should be, of interest to these communities, coped with the challenge of addressing and analyzing the dramatic political changes in post-independence Ukraine.

This survey first focuses on political science scholarship, projects designed to improve Ukraine's policy-making capacity, and other related activities associated with the several institutes, chairs, or programs in Canada concerned with Ukraine or with the post-Soviet region. This institutional approach has significant drawbacks (I will not attempt to describe and assess the work of individual scholars), but it will ensure that this survey will not go beyond a reasonable length.

The political science scholarship of individuals who are not associated with the institutions noted above, and a Canadian initiative designed to foster the discipline of political science in Ukraine, will then be briefly discussed. This survey will focus on individuals who hold or who have held full-time teaching or research positions at Canadian universities. However, the usual caveats apply. Such a survey cannot do full justice to complex developments in a fluid and constantly changing academic environment, it simply provides an overview.

\section{THE CANADIAN INSTITUTE OF UKRAINIAN STUDIES}

Three historians have succeeded Krawchenko as director of the CIUS: Frank Sysyn (acting director, 1991-92), Zenon Kohut (acting director, then director, 1993-2012), and Volodymyr Kravchenko (director, 2012-17). For much of the 1990s Krawchenko, then living and working in Ukraine, served as a link between the CIUS and Ukraine's academic community and government circles. However, for a substantial period of time no political scientists were formally affiliated with the CIUS.

This meant that the CIUS was left without significant political science expertise at a critical time when the political scene in Ukraine, stagnant and predictable prior to the late 1980s, quickly became more dynamic. The

\footnotetext{
2 One prominent example is the Ukrainian Catholic University (UCU) in Lviv, which has engaged in active fund-raising in the Ukrainian diaspora. For more information about the UCU and its fundraising activities, see http://ucu.edu.ua/eng/.
} 
entire course of Ukraine's post-Soviet development has been seriously influenced by this country's often dysfunctional politics and the poor performance and often corrupt behaviour of its dominant political elites. In addition, Ukraine faced increasing external challenges at a time when its increasingly dynamic civil society vigorously pressed for socio-economic and political reforms. Thus the absence of an "in-house" political science (and overall social science) capability at the CIUS for much of the period following 1991 was unfortunate.

One measure to compensate for this lacuna was the establishment in 1990, by the CIUS, of the Stasiuk Program on Contemporary Ukraine, which was intended to provide current analyses of events in Ukraine for the scholarly community, government, media, and the general public. Between 1994 and 2014 the program's work was associated primarily with David Marples, a specialist in twentieth-century East European history (with a focus on Ukraine, Belarus, and Russia) at the University of Alberta, and the program concentrated on a number of politically relevant topics such as Ukraine's relations with Russia, the Chornobyl nuclear disaster and its ramifications, and the consequences of the Orange Revolution of 2004. Between 2007 and 2015 this program also sponsored a blog page, "Current Politics in Ukraine," which, apart from providing analyses of current events in Ukraine, served as a forum for debate and discussion concerning issues such as the controversial legacy of the wartime Organization of Ukrainian Nationalists (OUN) and Ukrainian Insurgent Army (UPA) in present-day Ukraine.

A recent and more significant effort to increase the social science profile of the CIUS was the establishment, in 2013, of the Contemporary Ukrainian Studies Program (CUSP), initially called the Centre for Political and Regional Studies, with the aim of fostering interdisciplinary and comparative scholarship. The ambitious long-term objective of this new program, which incorporates the Stasiuk Program,

is to become the leading North American social science research hub exploring Ukraine's developmental path, creating knowledge that will be relevant theoretically as well as in public policy terms. It will serve as a vital link connecting social scientists in Ukraine with their counterparts in the West, providing access mutually beneficial to both. ("Ukrainian Studies")

Bohdan Harasymiw, a political scientist who, after retiring in 2005 from the Department of Political Science at the University of Calgary, was initially appointed a CIUS research scholar, agreed to serve as the CUSP's acting coordinator. In addition, political scientist Taras Kuzio, a well-known specialist on post-communist politics who has written or edited many works 
on contemporary Ukraine, was appointed the program's first research associate in $2013 .^{3}$

The CUSP is in its infancy, but its creation reflects a welcome awareness of the need to strengthen the political science (and general social science) component of the CIUS's work. To date this program's activities have included the organization of a forum on "Trafficking of Women in Ukraine: Governmental and Nongovernmental Responses" and a symposium on the first anniversary of the Euromaidan Revolution. In addition, Harasymiw is currently the lead investigator of a three-year project on democratic reform of governance in Ukraine.

After Ukraine became independent, the CIUS began to vigorously develop ties with and provide support to scholars, students, and academic institutions in Ukraine. In particular, close co-operation has been fostered with the CIUS-sponsored Kowalsky Eastern Ukrainian Institute at Kharkiv National University, the Institute of Historical Research at Lviv National University, the National Academy of Sciences of Ukraine, the National University of Kyiv-Mohyla Academy, and Chernivtsi National University. The CIUS has also actively engaged in supporting democratic reforms in Ukraine. Its first major initiatives to this end were the Canada-Ukraine Legislative Cooperation Project (1996-2000), designed by the CIUS, and the Canada Ukraine Legislative and Intergovernmental Project (2000-04), both of which were financed primarily by the Canadian International Development Agency (CIDA). ${ }^{4}$ The major aims of these projects were to assist Ukraine's parliament in drafting crucial legislative documents and to support economic reforms in Ukraine. To achieve these aims, study groups of parliamentarians and senior government officials from Ukraine travelled to Canada, and specialized workshops and consultations in Ukraine followed these visits. The CIUS also managed the Ukraine Transparency and Election Monitoring Project in 2004, during the turbulent presidential elections that were the central focus of what became known as the Orange Revolution.

The CIUS has maintained a good record of organizing regular conferences, seminars, and workshops, many of which deal with or touch on issues related to political developments in Ukraine. The CIUS supports promising scholars in all fields of Ukrainian studies by providing scholarships as well as fellowships, and graduate and postgraduate students in political science have been frequent beneficiaries. At some point in their graduate studies, many of Canada's political scientists who currently conduct research on Ukraine have received financial support from the CIUS,

\footnotetext{
3 Detailed information about Taras Kuzio's publications and his other activities is available at http://www.betweeneuropeandrussia.com/.

4 In 2013 the agency merged with the Department of Foreign Affairs and International Trade, now called Global Affairs Canada.
} 
for example, Dominique Arel at the University of Ottawa, Marta Dyczok at Western University, John (Ivan) Jaworsky at the University of Waterloo, and Bohdan Kordan at the University of Saskatchewan.

In addition to its own scholarships and fellowships, the CIUS administers the Neporany Fellowship on behalf of the Canadian Foundation for Ukrainian Studies, and since this support is not limited to Canadian citizens, several fellowship recipients who conduct Ukraine-related political science research are now teaching abroad (e.g., Olena Nikolayenko at Fordham University and Olga Onuch at the University of Manchester). Recent examples of support for doctoral research in political science include the Neporany Fellowships granted in 2008 to Spyridon Kotsovilis (now teaching at the University of Toronto-Mississauga) for his research on "The Network is the Message: Complex Network Analysis and Mapping Mass Mobilization of Democratizing Revolutions in Ukraine and Serbia," in 2014 to Anastasiya Salnykova (Department of Political Science, University of British Columbia) for her research on "Deliberative Capacity in Post-Soviet Democratization: The Case of Inter-Cultural Relations in Ukraine," and in 2014 to Daniel Fedorowicz (University of Oxford) for his research on "Spatial Variation of Violence Within Ethnic Conflicts: Poland and Ukraine During World War II."

Although the CIUS's record of support for historical scholarship is very strong, support for the social sciences, including political science, has been considerably weaker. As noted above, a number of recent measures have been taken to correct this situation, but the CIUS Press website continues to reflect this weakness. Under "Politics" only six books are listed, the most recent (Harasymiw) published in 2002, whereas the number of books listed under "History" is much more impressive (although it should be noted that many of these publications are part of multivolume collections, or books published in Ukraine with the support of the CIUS). Much of this disparity can be explained by the strong emphasis on history that is often characteristic of chairs and institutes/centres devoted to the study of a particular country or ethnocultural group. Since the CIUS closely co-operates with scholars in Ukraine and publishes some of their works, this pattern of research and publishing also partly reflects a continuous and strong tradition of historical scholarship in Ukraine (even when it was under Soviet rule), as compared to the general underdevelopment of political science in Ukraine, even during the post-Soviet period.

Finally, most mainstream academic publishers will readily entertain publication proposals from scholars working on what are perceived to be currently relevant topics, but publishers are less enthusiastic about proposals from historians whose work is often perceived to have a more limited audience. In addition, large publishers can usually readily process manuscripts that require a quick turnaround. It is thus possible that some 
political science or other social science manuscripts that could have been submitted to the CIUS, which has a relatively small publishing operation, found other publishers. ${ }^{5}$ Nonetheless, more could be done by the CIUS to foster social science research and encourage publications dealing with current socio-political realities in Ukraine.

Disciplinary boundaries, however, are often rather ambiguous, and scholars working in a variety of areas can make major contributions to debates on politics and policy-making in Ukraine, as well as to our understanding of the context for these debates. For example, it is difficult to understand recent trends in relations between Ukraine and Russia outside of their historical context, and in the early 1990s the CIUS played a leading role in co-sponsoring a series of workshops on the Russian-Ukrainian encounter from the early modern period to the present day. ${ }^{6}$

The CIUS has also provided significant support to historians in Ukraine who conduct active research on what can be called the "politics of memory" and the "politics of history." Historians formerly associated with the CIUS, e.g., John-Paul Himka ("Legislating Historical Truth") and David Marples ("Ukraine and Russia"), have been active participants in the vigorous and ongoing political debate, both in Ukraine and in the diaspora, concerning the controversial legacy of Ukrainian nationalism (especially in the forms it assumed during World War II-the OUN and the UPA) and recent efforts to promote the decommunization of Ukraine.

\section{THE UNIVERSITY OF TORONTO AND ITS CHAIR OF UKRAINIAN STUDIES}

Since the Chair of Ukrainian Studies was established at the University of Toronto in 1980, it has been held by Paul Robert Magocsi, a historian with a strong interest in nationalism, particularly in nationalism among ethnic groups living in border areas. Magocsi has published widely in the fields of history, sociolinguistics, cartography, and studies of ethnicity and immigration. In the 1980s the chair held several scholarly conferences and conducted a public seminar in Ukrainian studies. However, in his capacity as a Ukrainianist, Magocsi decided to function as a research and publishing

\footnotetext{
${ }^{5}$ For examples of interesting social science monographs with a focus on Ukraine written by Canadian scholars, see the recent works of Popova (2012) and Fournier (2012).

6 The fourth workshop was devoted to the Russian-Ukrainian encounter after the demise of the Soviet Union, and its proceedings were published as a special edition of The Harriman Review ("Peoples, Nations, Identities: The Russian-Ukrainian Encounter").
} 
scholar first and foremost, maintaining a low public profile and minimizing his organizational and administrative duties ("Concluding Observations").

Nonetheless, the chair's activities are relevant to the study of politics in two interesting respects. First, Magocsi has consistently stressed the importance of studying the history of all ethnic groups in Ukraine. This is reflected, for example, in his A History of Ukraine: The Land and Its Peoples (1996; revised and expanded edition 2010) and This Blessed Land: Crimea and the Crimean Tatars (2014). Magocsi's emphasis on Ukraine's ethnocultural diversity is thus of great relevance to the contentious political debate in post-independence Ukraine regarding the relative virtues of "ethnic" as opposed to "civic" nation building projects. In a sense, much of Magocsi's work can be seen as providing both a history based rationale and a certain intellectual framework for those who support the idea of a diverse and inclusive multicultural Ukraine.

Magocsi's second contribution to the study of politics is more idiosyncratic, being associated with his long-time activity as a scholar/activist promoting Rusyn studies and Rusyn nationhood. He has written or played a major role in preparing a number of works designed to provide some of the underpinnings of a distinct Rusyn identity-e.g., Let's Speak Rusyn / Бісідуйме по-руськы (1978), the Encyclopedia of Rusyn History and Culture (2002), and With Their Backs to the Mountains: A History of Carpathian Rus' and Carpatho-Rusyns (2015) - and he has been described as "the person most responsible for the active promotion of the study of the Carpatho-Rusyn ethnic group in the world today" (Ziac 213-14). In addition, Magocsi served as a long-time chairman of the World Congress of Rusyns (he is now its honorary president), and is regarded as a semi-iconic figure in some Rusyn circles. According to one comment in a collection of essays in honour of Magocsi published on the occasion of his seventieth birthday in 2015, "He [Magocsi] is the father of the rebirth of Carpatho-Rusyn culture in the 20th and 21st centuries" (Righetti 49). In his role as a Rusyn activist, Magocsi has not only been a scholar, he has become a significant political actor, a central figure in a nation building experiment, and thus an object of research in his own right.

The controversies related to Magocsi's advocacy of the Rusyn cause that accompanied his appointment to the Chair of Ukrainian Studies at the University of Toronto in 1980 are largely a thing of the past, and there is a widespread consensus that Magocsi has made a significant contribution to Ukrainian studies. ${ }^{7}$ In addition, Magocsi has downplayed his role as a Rusyn nation builder; instead he refers to himself as an advocate or promoter of a

\footnotetext{
${ }^{7}$ See, for example, contributions to the special section of Nationalities Papers, vol. 39, 2011, on "The Scholar, Historian and Public Advocate: The Academic Contributions of Paul Robert Magocsi."
} 
Rusyn nationality. However, those interested in nation building projects and controversies in the complex setting of Eastern Europe, and the role of individual scholars in such projects and controversies, can learn a great deal by studying Magocsi's personal involvement in this distinct form of praxis.

Overall, however, in recent years the most important contribution to political science (and overall social science) scholarship and debates regarding Ukraine at the University of Toronto has been made by the Petro Jacyk Program for the Study of Ukraine, ${ }^{8}$ housed within (and co-operating with) the University of Toronto's Centre for European, Russian, and Eurasian Studies. Established in 2001 with the support of the Petro Jacyk Educational Foundation, the official mission of the program, "to promote scholarly understanding of the government, economy and society in contemporary Ukraine, as well as the country's history and culture," clearly places a priority on the social sciences. Likewise, the title of the program's prestigious annual post-doctoral fellowship in Ukrainian politics, culture, and society clearly highlights the study of politics.

Prior to 2001, the CIUS office in Toronto (responsible earlier for the Encyclopedia of Ukraine and now responsible for the Internet Encyclopedia of Ukraine project) organized seminars and occasional conferences at the University of Toronto, and it continued to do so after 2001. However, the CIUS office in Toronto now closely co-operates with the Jacyk Program, with which it has co-sponsored a number of events and which has benefitted a great deal from the contacts the CIUS established earlier. This is just one example of how the program has maximized the impact of its activities by working closely with other academic units at the University of Toronto, and it engages in joint projects and collaborates with all major Ukrainian studies programs in North America.

Overall, the Jacyk Program has encouraged a certain orientation away from a focus on history and culture and has heavily stressed the importance of studying political and socio-economic developments in Ukraine. For example, one of the current co-directors of the Jacyk Program is Lucan Way, a political scientist at the University of Toronto highly regarded for his research and publications on democratic transitions and the evolution of authoritarian rule in the former Soviet Union and in cross-regional perspective. ${ }^{9}$ Much of Way's research is indicative of a growing trend in

${ }^{8}$ Unless indicated otherwise, all information in this article about the Petro Jacyk Program and its activities was located at the program's website (http://sites.utoronto.ca/jacyk/index.html). Details concerning all Petro Jacyk Program activities to date are located online at this website.

${ }^{9}$ Way's monographs (2010 [co-author] and 2015) and articles have focused on the dynamics of hybrid democratic-authoritarian rule, the sources of political competition in the former Soviet Union, and the durability of authoritarian regimes. 
political science research on Ukraine: including Ukraine as a case study in publications that deal with a number of countries to help illustrate and throw light on general political processes from a genuinely comparative perspective.

Another important feature of the Petro Jacyk Program is its emphasis, noted in its mission statement, on encouraging scholars from other universities in Ontario to participate in Petro Jacyk Program activities. Such encouragement is reflected in the current composition of the program's coordinating committee, which includes scholars such as Olga Andriewsky (History, Trent University), Marta Dyczok (History/Political Science, Western University), Tanya Richardson (Anthropology, Wilfrid Laurier University), and Frank E. Sysyn (CIUS Toronto Office and History, University of Alberta). Dyczok, for example, has organized a number of workshops and conferences for the Petro Jacyk Program that feature various aspects of the media and politics in Ukraine. Thus, over time almost all scholars in Ontario who conduct research on Ukraine have been drawn into some of the program's activities.

Petro Jacyk Program activities include conferences, workshops, panel discussions, graduate symposia, lectures, and cultural events; in recent years the Petro Jacyk Program has sponsored or co-sponsored an average of twenty to thirty activities annually, many of which have involved a considerable number of participants and a wide range of topics. Common themes of these activities include the electoral process and electoral aftermaths; Ukraine-Russia relations and Ukraine's foreign policy (including Ukraine-EU relations); the politics of history and memory; the media and media politics; Crimea, the Crimean Tatars, and Ukraine's role in the Black Sea region; corruption and the politics of business; energy politics; and policies toward minorities. In short, the Petro Jacyk Program has an enviable record of organizing successful events, and its establishment has led to a significant growth in the number of Ukraine related scholarly activities at the University of Toronto.

THE CHAIR OF UKRAINIAN STUDIES AT THE UNIVERSITY OF OTTAWA

The Chair of Ukrainian Studies ${ }^{10}$ at the University of Ottawa was formally established in 1993, but it initiated a full program of regular activities in

\footnotetext{
10 Unless indicated otherwise, all information in this article about this chair and its activities is from the chair's websites, http://socialsciences.uottawa.ca/ukraine/and https://www.chairukr.com/. When preparing this article, however, I could no longer access materials that had earlier been available there (e.g., the programs of the Danyliw seminars and the papers presented at these seminars).
} 
2003 when the chair's current holder, political scientist Dominique Arel, was appointed. Arel's interests include nationalism, language policies, census politics, and the politics of identity; he has co-edited two books and has written a number of articles that address these and other issues in Ukrainian and other contexts. ${ }^{11}$ As befits the chair's location in Canada's capital, it strongly emphasises the study of politics as well as social studies approaches to understanding contemporary Ukraine. The chair's official description is "the only chair in Canada and outside of Ukraine dedicated specifically to the study of contemporary Ukraine or related topics dealing with politics, economy and sociology of Eastern European states and the Post-Soviet space."

The Chair of Ukrainian Studies at the University of Ottawa has limited administrative support and, like the John Yaremko Chair at the University of Toronto, it is largely a one-person operation. However, in 2015 the Ottawa chair received a sizeable donation that allowed it to offer doctoral scholarships in political science, sociology, anthropology, and other fields associated with the chair. In addition, soon after Arel assumed his position, the chair attracted funding from the Wolodymyr George Danyliw Foundation (Toronto) in support of an ambitious annual Danyliw Research Seminar. In line with the chair's overall orientation, this three-day event generally favours presentation proposals that focus on methodologically rigorous treatments of issues relevant to contemporary Ukraine, and most participants have social science backgrounds. Several prominent scholars serve on the selection committee that evaluates the proposals, and those delivering presentations include an interesting mix of scholars from Canada, the United States, Ukraine, and other European countries. The seminar's format is designed to foster discussion, and it serves as a stimulating forum that helps young and early-career scholars to obtain useful feedback regarding their current research.

A distinctive feature of the Chair of Ukrainian Studies at the University of Ottawa is its close co-operation with scholars in France who have conducted research on Ukraine and its neighbours. A number of French scholars serve or have served on the Danyliw Seminar's selection committee; they include Ioulia Shukan (Université Paris-Ouest, Nanterre), Anna Colin Lebedev (L'École des Hautes Études en Sciences Sociales, Paris), and Alexandra Goujon (Université de Bourgogne, Dijon). From 2010 onward the chair has been a co-sponsor of the International Social Science School in Ukraine, which is primarily funded by the chair's long-term partner, the Danyliw Foundation. This summer school was inaugurated in 2009 by the Embassy of France in Ukraine, which continues to be a leading partner in this

${ }^{11}$ See the note about Arel's publications at http://nationalities.org/about/board-ofdirectors/dominique-arel. 
project, and scholars from a number of academic institutions in France are represented on the school's organizing team and on permanent faculty. Held in a different city of Ukraine every year, the school adheres to a workshop format that encourages extended discussion of presentations of research concerning particular critical themes. For example, the theme of the 2016 summer school held in Kharkiv was "War and Violent Conflict in Socialist and Post-Socialist Societies." The chair's international contacts are facilitated by Arel's long-time role as the convention director of the Association for the Study of Nationalities, which focuses on studies of ethnicity, ethnic conflict, and nationalism, publishes the journal Nationalities Papers, and holds a large annual world convention at Columbia University in the US and occasional conventions in Europe.

The Chair of Ukrainian Studies at the University of Ottawa co-sponsors the Annual Ivan Franko Memorial Lecture at the University of Ottawa and publishes an irregular newsletter, The Ukraine List (UKL), which publicizes chair sponsored activities and, more significantly, includes the texts of articles that discuss recent developments in Ukraine, debate contentious issues in Ukrainian studies, and contain useful references to recent publications concerning Ukraine. The $U K L$ appears most frequently during periods of crisis in Ukraine, and the chair co-operated with the CIUS in 2004 to produce a regular bulletin on events in Ukraine that provided timely coverage of the Orange Revolution.

In the absence of a significant local support network of Ukrainianists such as that found in Toronto and Edmonton, the Ottawa Chair of Ukrainian Studies has done a good job with limited resources of promoting social science scholarship on Ukraine. One might expect that its work would be complemented to a certain extent by the activities of the Institute of European, Russian and Eurasian Studies at Ottawa's Carleton University, one of only two institutes/centres at Canadian universities that have significant programs devoted to the study of the post-Soviet region (the other, mentioned above, is the Centre for European, Russian, and Eurasian Studies at the University of Toronto). However, that institute has devoted little attention to Ukraine in its courses and public events, its regular faculty has not demonstrated a serious interest in research on Ukraine, ${ }^{12}$ and overall IERES's activities are characterized by a certain Russocentrism.

\footnotetext{
12 I am aware of only two exceptions. In the mid-1990s Andrea Chandler, a political scientist at Carleton University affiliated with IERES, wrote an article on social policy in Ukraine, another on Ukraine's military (1996), and a book (1998) that briefly discussed Ukraine. She does not, however, appear to have maintained an interest in this country (her later publications have focused on Russia). The anonymous reviewer of a draft version of this article also brought to my attention an article
} 


\section{“OTHER” SCHOLARS}

A number of political scientists with strong interests in Ukraine live and work beyond Edmonton, Toronto, and Ottawa, and generally do not have formal ties to the Ukrainian studies institutions mentioned above, although they may participate in some of their activities. Scholars in this category who currently hold full-time teaching positions in political science (or in the case of one scholar, a joint history and political science appointment) include Marta Dyczok at Western University (her research interests include the mass media, migration, and the politics of history); Olena Hankivsky at Simon Fraser University (gender politics, health-care policy); John (Ivan) Jaworsky at the University of Waterloo (civil-military relations, the legacies of Soviet dissent, government policies regarding minorities); Bohdan Kordan at the University of Saskatchewan (nationalism and ethnic conflict, the politics of state/minority relations); Mikhail Molchanov at St. Thomas University (foreign and security policy, political leadership, state-building and regionalism); Maria Popova at McGill University (judiciaries and the rule of law, judicial reform/corruption); and Lyubov Zhyznomirska at St. Mary's University (European Union politics, citizenship and migration studies).

A number of other Canadian scholars who are not political scientists conduct research on Ukraine that is relevant to the study of politics and policy-making in Ukraine. For example, a number of Canadian scholars, specialists on the history of Ukraine (e.g., John-Paul Himka and David R. Marples at the University of Alberta, and Serhy Yekelchyk at the University of Victoria) have been active participants in contentious debates about the most appropriate ways of dealing with Ukraine's most difficult and painful historical legacies - debates that have had a great impact on the political and intellectual scenes in Ukraine. Several Canadian scholars who are anthropologists or sociologists also conduct research on Ukraine; they include Anna Fournier at the University of Manitoba (human rights, youth mobility, social movements, collective violence and crime); Natalka Khanenko-Friesen at the University of Saskatchewan (social movements, protest culture, and volunteerism); Anton Oleynik at Memorial University (modernization and administrative reform, power elites); and Tanya Richardson at Wilfrid Laurier University (environmental politics, policies, and activism). As it is sometimes difficult to determine what kinds of research should be considered politically relevant, several other names could probably be added to this list.

prepared by two other political scientists at Carleton University, Jon H. Pammett and Joan DeBardeleben. 


\section{Promoting the Study of Political Science In UKRAINE}

The Canadian federal government has consistently supported reforms in Ukraine, and democracy promotion has been an important component of the activities it sponsored in Ukraine through CIDA and other government departments/agencies. No attempt is made here to describe these varied activities or assess their effectiveness. Although its initiators did not have a significant prior connection to Ukraine, one large and innovative project is described below because of the way in which it mobilized Canadian political scientists to help scholars in Ukraine to promote public awareness of the importance of democratic practices and human rights and to establish a framework for a community of political science scholars in Ukraine.

Political science ("politolohiia") did not exist as a discipline in Soviet Ukraine. This vacuum began to fill soon after Ukraine became an independent state, but often by scholars with dubious credentials who had earlier specialized in and taught courses (compulsory for all students in Soviet Ukraine's system of higher education) on "scientific communism," "the history of the CPSU," "Marxist-Leninist theory," and so on. In the 1990s Canadian scholars trying to establish fruitful ties with scholars and institutions conducting political science research in Ukraine thus found it difficult to find partners who were aware of general developments in the field, and with whom they could co-operate. ${ }^{13}$

An important initiative to change this situation was taken by George Perlin of the School of Policy Studies at Queen's University: in the mid-1990s he initiated what became "The Democratic Education Project" (1998-2003). Funded primarily by CIDA, this project aimed to build a core of personnel in Ukraine who, with the help of Canadian scholars, would introduce a curriculum, on the study of democracy, to be used throughout universities in Ukraine. This was followed by the "Building Democracy Project" (2004$10 / 11$ ) to consolidate and extend the work of the previous project. ${ }^{14}$

To develop such a curriculum, forty-seven scholars from Ukraine, in four separate groups, underwent an intensive graduate program, taught by Canadian scholars, to introduce them to the state of the literature on democracy. Each group then designed a curriculum for a course appropriate for Ukraine, and, after a conference to settle on a final curriculum, an accompanying textbook was prepared in Ukraine with the assistance of Canadian partners. This textbook, titled Osnovy demokratii (Fundamentals of Democracy, 2002), has gone through three editions (3rd ed., 2009), 11,000

\footnotetext{
13 On the state of and problems confronting the discipline of political science in Ukraine, see Osin, and Starish.

14 Unless indicated otherwise, all information in this article about these two projects and their activities was located at http://www.queensu.ca/sps/bdu/index.html.
} 
copies have been distributed to post-secondary institutions, and some 250 post-secondary institutions in Ukraine have adopted it as a textbook.

At a time when few such works were available in Ukraine, the Queen's University project also arranged for the translation into Ukrainian of a number of important works in political science and prepared separate textbooks on democracy and human rights for use in secondary schools. The project placed a special emphasis on helping to reform the Ministry of Internal Affairs, and a series of textbooks on topics such as democratic policing, racial profiling, combating racism, and gender and policing were prepared for Ukraine's universities and technical colleges. ${ }^{15}$

It is difficult to assess the impact of "The Democratic Education Project" (1998-2003) and similar projects aiming to foster democracy in Ukraine. However, a strong emphasis was placed on ensuring the effectiveness of the courses resulting from this project (e.g., a special course was prepared on the methods of teaching civic education in pedagogical universities and professional development institutes). The project undoubtedly had a positive impact on the development of a democratic political culture in Ukraine, and it also led to a significant increase in the political science expertise of a considerable number of scholars in Ukraine. Prominent "alumni" of the project included Antonina Kolodii, one of the best known and most prominent political scientists in Ukraine, and the respected analyst Volodymyr Fesenko, head of the Penta Center of Applied Political Studies (Kyiv).

\section{ASSESSING CANADA'S CONTRIBUTIONS}

Canada's Ukrainian studies infrastructure and its political science community have generally done a good job of promoting a better understanding of the nature and implications of political developments in Ukraine after the collapse of the Soviet Union. The CIUS, which in 1991 already had a fifteen-year history of encouraging research on Ukraine, played a significant role in Ukraine's first years of independence by providing useful advice and analysis to those trying to make sense of crucial developments, such as the frictions that quickly emerged between Ukraine and Russia. CIUS seminars, workshops, and conferences, as well as CIUS

15 A partial list of the publications this project sponsored can be found at http://www.queensu.ca/sps/bdu/publications.html. All of the items on that list were published in the Ukrainian language. They include translations of a number of basic texts by Canadian scholars on topics (e.g., participatory democracy, regulating political finance, minority rights) that, at the time of publication, were poorly covered in the existing social science literature available in Ukraine. 
scholarships and fellowships, have helped to foster a new generation of scholars, who in the last twenty-five years have been appointed to a number of positions in political science and to other social science departments in universities from Vancouver to Halifax.

Over time the CIUS has increased its emphasis on support for research in the social sciences, including political science, and this is also a priority of the more recent arrivals on the Ukrainian studies scene. Thus both the Petro Jacyk Program at the University of Toronto and the Chair of Ukrainian Studies at the University of Ottawa have stressed the importance of addressing socio-political and socio-economic issues in Ukraine and have provided scholars with useful new venues for scholarly debate and discussion.

Whereas past academic research on Ukraine was almost exclusively conducted by scholars born in Ukraine or with family ties to Ukraine, a positive trend is the growing interest in Ukraine of scholars without such roots. Among Canada's political scientists this trend is exemplified by Lucan Way and Dominique Arel, who, in addition to conducting their own research on Ukraine, have assumed organizational roles in the Ukrainian studies community. In the process, both of these scholars have made contributions to "mainstreaming" Ukrainian studies by consistently stressing the need to place social science research on Ukraine within a broad comparative framework and to improve the methodological skills of those conducting such research.

Canada has also played a useful role in fostering a political science community in Ukraine. For example, the CIUS has provided numerous scholars in Ukraine with research grants and opportunities to lecture and conduct research in Canada. The International Social Science School in Ukraine, co-sponsored by the Chair of Ukrainian Studies at the University of Ottawa, has helped to improve the methodological skills of many young scholars in Ukraine. The Democratic Education and Building Democracy projects initiated by George Perlin of Queen's University put in place some of the educational infrastructure needed to promote democratic values in Ukraine.

Ukraine is currently under severe pressure to engage in serious socioeconomic and political reforms, while the country's oligarchic elites are doing their best to maintain the corrupt status quo. The progress of Ukraine's integration with Europe faces serious challenges, while Russia's policies continue to undermine Ukraine's territorial integrity. Ukraine's difficult domestic situation and its many foreign-policy challenges ensure that there will be a continuing need for good quality social science research on Ukraine for many years to come.

Canadian scholars could make a significant contribution to this research, and they are well-positioned to assist in addressing a number of practical 
policy issues that are, or could be in the future, of great relevance to Ukraine. For example if, over time, there are significant political changes in Russia, and Ukraine establishes more normal relations with its eastern neighbour, the lessons that have been learned from Canada's experience of dealing with a wide range of contentious policy issues affecting its relations with the United States (e.g., regulating the access of cultural products from the United States to Canadian media markets; effectively managing a long and porous border; cross-border water and other environmental problems) could be applied, at least partially, to Ukraine's future relations with Russia. ${ }^{16}$ Canada's experience in dealing with a wide range of issues related to the politics of cultural pluralism (language policies, a large national minority and indigenous peoples, immigrant and refugee settlement, fighting racism and discrimination) are also relevant to a number of politically charged issues facing Ukraine today. Canada, a decentralized country with strong traditions of local self-government and the promotion of ethical behaviour of civil servants, can also help Ukraine deal with the enormous challenges of reforming its inefficient, hypertrophied, and corruption-prone bureaucratic structures.

Few of Canada's political scientists who focused on Ukraine in the past have expertise in public administration or the other areas noted above. However, one of the significant trends of recent years is the rapidly growing number of politicians and government officials in Ukraine who are proficient in English. Thus it is increasingly convenient for scholars and practitioners without a knowledge of Ukrainian or Russian to conduct research in Ukraine or to effectively interact with their peers in Ukraine, and this has created new opportunities for mutually beneficial scholarly and practical co-operation between Canada and Ukraine.

\section{CONCLUSIONS}

The CIUS, the two Chairs of Ukrainian Studies in Canada, and the Petro Jacyk Program all represent different facets of the traditional area-studies approach. This approach stresses the importance of encouraging in-depth

\footnotetext{
16 The late Canadian historian Orest Subtelny (York University) was the director of a major CIDA-funded project, "Promoting Ukraine's Global Integration" (2006-10), which focused heavily on these and other issues. This project placed a strong emphasis on applying Canada's experience of negotiating with the United States to the challenges Ukraine has faced in dealing with Russia. I am not aware of any major publications resulting from this project's activities. For information about a previous (2001-05) CIDA-funded project that Subtelny also directed, see "York University Hosts 'Democracy and Good Governance' Project on Ukraine.”
} 
interdisciplinary knowledge of a particular country or region, and is often considered somewhat old-fashioned. A greater emphasis is now placed on the need for methodologically rigorous comparative scholarship within the framework of disciplines such as political science and sociology. The Ukrainian studies network in Canada has accepted the need for change, and in recent years there has been an attempt to combine the positive features of the area-studies approach with the virtues of the comparative approach.

Some might argue that, with time, the need for the institutes, chairs, and programs discussed above will disappear, especially if scholars interested in Ukraine increasingly populate the established disciplines. Good research can be and has been conducted by individual scholars without the support of a Ukrainian studies infrastructure. However, the focus on Russia, which dominated scholarship on the Soviet Union, has left a significant long-term legacy, and there is still a strong tendency to view present-day Russia as the legitimate great-power successor of the Soviet Union, entitled to maintain a sphere of influence over certain neighbouring countries such as Ukraine. This Russocentrism has been a powerful force in academia, and the presence of a strong Ukrainian studies community that is fully integrated into Canada's academic life, but also maintains a distinct identity, can play a major role in counterbalancing such Russocentrism.

Given the frequent interactions between scholars in Canada and the United States, it is tempting to compare the treatment of Ukraine by political science disciplines in these neighbouring countries. The two main centres of Ukrainian studies, the CIUS (Canada) and the Harvard Ukrainian Research Institute (HURI) (United States), have both focused heavily on history at the expense of the social sciences. Outside of the HURI, however, a number of American political scientists conduct active research on Ukraine; they include both scholars of Ukrainian background (e.g., Alexander Motyl, Oxana Shevel, Serhiy Kudelia) and scholars with non-Ukrainian backgrounds (e.g., Henry Hale, Paul D’Anieri, Margarita Balmaceda). American government support for research on Ukraine and the entire post-Soviet region declined after the end of the Cold War, but growing concerns in recent years about Russia's aggressive foreign policy and military buildup, in particular the geopolitical ramifications of the Russian state's annexation of Crimea and its active intervention in Eastern Ukraine, have led to a renewed interest in Ukraine and greater support for research on Ukraine. Increasing opportunities for such research have coincided with the emergence of a new cohort of younger scholars interested in Ukraine who are well versed in comparative research; this combination has had, and continues to have, positive implications for political science scholarship regarding Ukraine in the United States. This positive picture is not surprising given the welldeveloped infrastructure (including an extensive network of universities and a large number of well-funded think tanks) for academic research in the 
United States, and America's significant geostrategic interests in the postSoviet region. There is much room for improvement in the infrastructure of Canadian political science research on Ukraine, but given Canada's significantly smaller academic and think tank communities, as well as Canada's much more modest global presence and ambitions, it is not surprising that in many respects Canada lags behind the United States in such research.

I do not dwell here on the many chronic problems that face Ukrainian studies in Canada; they include academic pressures that periodically require the study of Ukraine to justify its existence, and the pressure on Ukrainian studies chairs to engage in continuous fund-raising to ensure the future of their positions. In spite of these and other challenges, this infrastructure has endured in an environment that is often hostile to area studies, and Ukrainian studies in Canada have demonstrated considerable flexibility in adopting new approaches to understand and to deal better with the dramatic political and socio-economic challenges that still face Ukraine. In turn, the discipline of political science will benefit from this success, for it has much to learn from recent developments in Ukraine, a country that has confounded, and continues to confound, many observers.

\section{Works Cited}

Chandler, Andrea. Institutions of Isolation: Border Controls in the Soviet Union and Its Successor States, 1917-1993. McGill-Queen's UP, 1998.

---. "Social Policy and Political Discourse in Post-Soviet Ukraine." Journal of Ukrainian Studies, vol. 21, no. 1-2, 1996, pp. 191-211.

---. "Statebuilding and Political Priorities in Post-Soviet Ukraine: The Role of the Military." Armed Forces and Society, vol. 22, no. 4, July 1996, pp. 573-97.

Fournier, Anna. Forging Rights in a New Democracy: Ukrainian Students Between Freedom and Justice. University of Pennsylvania P, 2012.

Harasymiw, Bohdan. Post-Communist Ukraine. Canadian Institute of Ukrainian Studies P, 2002.

Himka, John-Paul. "Legislating Historical Truth: Ukraine's Laws of 9 April 2015." $A b \quad 21 \quad$ Imperio, April 2015, http://www.academia.edu/12056628/Legislating_Historical_Truth_Ukraines_L aws of 9 April 2015. Accessed 15 June 2016.

Kolodii, Antonina, et al. Osnovy demokratii. 1st ed., V.I. Press, 2002; 3rd revised ed., Astroliabiia, 2009.

Magocsi, Paul Robert. "Concluding Observations on the Symposium." Nationalities Papers, vol. 39, 2011, pp. 129-34.

---. Encyclopedia of Rusyn History and Culture. U of Toronto P, 2002.

---. Let's Speak Rusyn / Бісідуйме по-руськы. Transworld Publishers, 1978.

---. With Their Backs to the Mountains: A History of Carpathian Rus' and CarpathoRusyns. CEU P, 2015. 
Marples, David. "Ukraine and Russia: Rewriting Histories." Essays by David Marples, 2 June 2016, https://davidrmarples.wordpress.com/2016/06/02/ukraine-andrussia-wars-over-the-past/. Accessed 14 June 2016.

Osin, Vadim. "Nauka v novom mire: Tri siuzheta genezisa regional'noi politologii $\mathrm{v}$ postsovetskoi Ukraine." Ab Imperio, no. 4, 2015, pp. 239-93.

Pammett, Jon H., and Joan DeBardeleben. "The Meaning of Elections in Transitional Democracies: Evidence from Russia and Ukraine." Electoral Studies, vol. 15, no. 3, 1996, pp. 363-81.

"Peoples, Nations, Identities: The Russian-Ukrainian Encounter." A Special Edition of The Harriman Review, vol. 9, no. 1-2, Spring 1996, pp 1-159.

Popova, Maria. Politicized Justice in Emerging Democracies: A Study of Courts in Russia and Ukraine. Cambridge UP, 2012.

Righetti, John. "Congratulatory Message." A Jubilee Collection: Essays in Honor of Professor Paul Robert Magocsi on His 70th Birthday. Edited and compiled by Valerii Padiak and Patricia A. Krafcik. Valerii Padiak Publishers, 2015, p. 49.

"Special Section: The Scholar, Historian and Public Advocate. The Academic Contributions of Paul Robert Magocsi." Nationalities Papers, vol. 39, 2011, pp. 95 134.

Starish, Oleksandr. "Politychna nauka v Ukraini: 20 rokiv nezalezhnosty." Krytyka, no. 179-80, 2012, pp. 27-29.

"UCA Staff." University of Central Asia, http://www.ucentralasia.org/About/UcaStaff\#BohdanKrawchenko. Accessed 27 June 2016

"Ukrainian Studies." Canadian Institute of Ukrainian Studies, https://uofa.ualberta.ca/arts/research/canadian-institute-Ukrainian studies/research-areas-and-programs/Ukrainian studies. Accessed 25 June 2016.

Way, Lucan. Pluralism by Default: Weak Autocrats and the Rise of Competitive Politics. Johns Hopkins UP, 2015.

Way, Lucan, and Steven Levitsky. Competitive Authoritarianism: Hybrid Regimes After the Cold War. Cambridge UP, 2010.

"York University Hosts 'Democracy and Good Governance' Project on Ukraine." The Ukrainian Weekly, 12 Aug. 2001, http://www.ukrweekly.com/old/archive/2001/320124.shtml. Accessed 25 June 2016.

Ziac, Martin Fedor. "Professors and Politics: The Role of Paul Robert Magocsi in the Modern Carpatho-Rusyn Revival." East European Quarterly, vol. 35, 2001, pp. 213-32. 